\title{
リポ蛋白 (a)の冠動脈硬化進展度に及ぼす影響
}

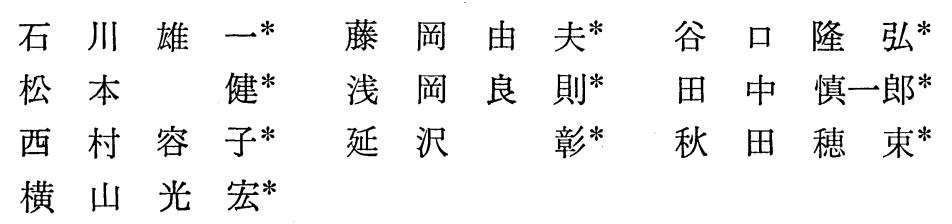

\section{I. 目 的}

高コレステロール血症が冠動脈硬化症の危険因 子であることが，実験的にも疫学的にも明らかに されてきた. 高コレステロール血症を治療するこ とにより虚血性心疾患の発生率が抑制されたとい う Lipid Research Clinics の報告1) 以来, 虚血性 心疾患における高コレステロール血症を治療する ことの重要さが強調されている.しかしながら, わが国では正脂血症者にも虚血性心疾患がみられ， 高コレステロール血症だけでは冠動脈硬化発生を 説明できない，そこでわれわれは最近，新たな危 険因子と考えられているリポ蛋白 (a) [Lp(a)]につ いて ${ }^{2)}$, 虚血性心疾患との関連や, 他の危険因子 との関連を検討した結果, Lp(a) が冠動脈硬化病 変の重症度に関連し, 他の危険因子とは独立した 因子であることを見いだしたので報告する。

\section{II. 方 法}

対象 : 神戸大学第一内科に入院し, 診断的冠動 脈造影 (CAG) を施行した患者を対象とした. 正 常值の確認には一般健康診断で異常の全く認めら れない者を対象とした。炎症性疾患, 肝疾患, 悪 性新生物は対象から除外した。

患者背景 : 契煙歴, アルコール量については問

* 神戸大学医学部第一内科 本研究の一部は大阪ガスグループ福礼財団助成によった. 原稿受取日：1991 年 3 月 8 日 採用決定日：1991 年7月 10 日
診より得た. 血圧は人院中数回測定し, その血圧 が, 収縮期 $160 \mathrm{mmHg}$ または拡張期 $95 \mathrm{mmHg}$ 以 上の患者あるいは高血圧治療中の患者を高血圧患 者とした. 糖尿病患者は, 空腹時血糖 $140 \mathrm{mg} / \mathrm{d} l$ 以上, $\mathrm{HbA}_{1 \mathrm{c}} 6.5 \%$ または $\mathrm{HbA}_{1}$ が $8.0 \%$ 以上, お よび糖尿病治療中の患者とした. 体格指数 $(\mathrm{BMI})$ は体重 $(\mathrm{kg}) /[\text { 身長 }(\mathrm{m})]^{2}$ を用い算出した.

冠動脈造影および 評価法: 冠動脈造影 (CAG) は Judkins 法で行い，6方向より60枚/秒で撮影 した. 冠動脈狭窄度は $\mathrm{Lp}(\mathrm{a})$ 值を知らない 2 3 名 の医師の一致により評価された. 狭窄度は AHA の分類に従い, Gensini の方法 ${ }^{3)}$ により冠動脈狭 窄度スコア $(\mathrm{CS})$ を算出した。ささらに $75 \%$ 以上の 㹨窄度を有する主幹冠動脈を一病変枝とし, その 数より $0(0$ VD) から 3 枝病変 (3 VD) の 4 群に分 類した.

Lp(a), 脂質, アポ蛋白の測定 : 採血は入院時 12 時間以上絶食させた早朝空腹時に行った. 急性心 筋梗塞患者に颃いては発症後 1 か月以上経過し安 定した時期, あるいは 3 か月後の再造影入院時に 同様の採血を行った。

Lp(a) は一元放射免疫桩散法 (Lp(a) Combi. R.I.D. キット, Immuno AG. Vienna)により測定 した ${ }^{4)}$. 測定感度の下限は $5 \mathrm{mg} / \mathrm{d} l$ であった. 血 中コレステロール (TC), トリグリセライド (TG) は東芝自動分析装置 (TBA80S) を用いた酵素法に て測定した. HDLコレステロール (HDL-C) はへ パリンーカルシウム沈澱法, アポ蛋白 $\mathrm{A} 1$, および B (Apo A1, Apo B) は免疫比濁 (TIA) 法5), レシチ 


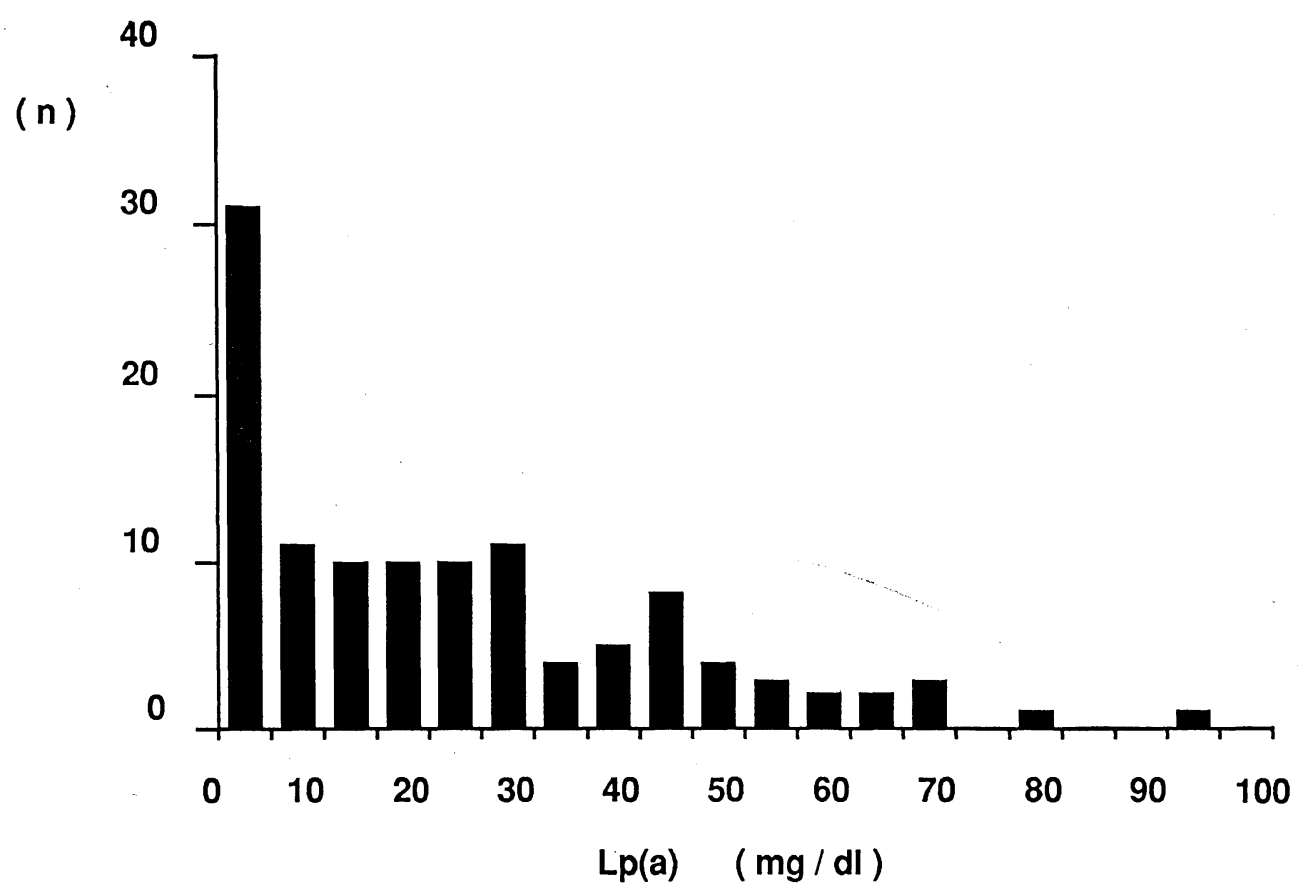

Fig. 1 Frequency distribution of $\mathrm{Lp}$ (a) levels in 116 studied individuals.

ン:コレステロールアシルトランスフェラーゼ (LCAT) は赤沼法で測定した. LDL コレステロー ル (LDL-C) は Friedewald の式 $(\mathrm{LDL}-\mathrm{C}=\mathrm{TC}-$ HDL-C-TG/5) を用いて算出した ${ }^{6)}$.

統計的解析 : 結果は, 平均值士標準誤差で表し た. 統計処理には, Kruskal-Wallis 法, Wilcoxon rank sum test, Spearman's rank correlation coefficient, Multivariate Analysis を用いた.

\section{III. 結 果}

対象：対象は 116 名, うち 98 名は CAG 施行 患者, 18 名は一般健康人であった. 男性 83 名, 女性 33 名, 平均年齢 57 歳 (35 歳 82 歳) であっ た. 98 名の内訳は, 狭心症 45 名, 心筋梗塞 52 名, 僧帽弁腱索断裂 1 名であった.

Lp(a)の分布：Fig. 1 に今回対象者 116 名の Lp(a) の度数分布を示す. 著しく 0 に傾いた分布 を示し，他の報告と同様であった。しかしながら $45 \mathrm{mg} / \mathrm{d} l$ にも小さなピークを認めた. 今回対象者 の平均值は $22.1 \pm 1.9 \mathrm{mg} / \mathrm{d} l$ であり, 中央值は 19.4 $\mathrm{mg} / \mathrm{d} l$ であった.
$\mathrm{Lp}$ (a) と CS, 病変枝数との関係 : 血中 $\mathrm{Lp}(\mathrm{a})$ 值 と Gensini 法による CS との間には有意の相関が あった。 Lp(a)のほかにも, Apo B, Apo B/A1 比, TC, LDL-C, LDL-C/HDL-C, LDL-C/TC \& CS と有意の相関を示した.

病変枝数別の群間における年齢, BMI, 脂質, リポ蛋白，アポ蛋白などの值をみると Table 1 の ごとく, Lp(a) は 0 枝群では $8.7 \pm 2.8 \mathrm{mg} / \mathrm{d} l$ であ り, 1 枝群 $22.6 \pm 3.2 \mathrm{mg} / \mathrm{d} l, 2$ 枝群 $25.8 \pm 4.2 \mathrm{mg} /$ $\mathrm{d} l, 3$ 枝群 $36.4 \pm 4.7 \mathrm{mg} / \mathrm{d} l$ と 0 枝群に比べ病変枝 数が多いほど有意に増加していた $(\mathrm{p}<0.001)$. LDL-C/HDL-C, Apo B, Apo B/A1 比も病変枝数 が多いほど増加していた. HDL-C は, 病変枝数 が多いほど低值であった。

さらに, Fig. 2 に示すように病変枝数の各群間 にも有意差を認め, 冠動脈病变枝数が多いほど Lp(a) 值が高いことが示された.

一般健康診断で正常と判定された 18 名の平均 $\mathrm{Lp}$ (a) 值は $8.9 \pm 2.5 \mathrm{mg} / \mathrm{d} l$ であり, $0 \mathrm{VD}$ 群と同 様の值であった. 有病枝群との比較でも同様の結 果が得られた。 
リポ蛋白 (a)の冠動脈硬化進展度に及ぼす影響

Table 1 Some characteristics and lipid levels of the series

\begin{tabular}{|c|c|c|c|c|c|c|}
\hline & \multicolumn{6}{|c|}{ Kruskal-Wallis test } \\
\hline & $0 \mathrm{VD}$ & $1 \mathrm{VD}$ & $2 \mathrm{VD}$ & $3 \mathrm{VD}$ & Total & \\
\hline $\mathrm{n}$ & 14 & 38 & 24 & 22 & 98 & \\
\hline Age (yr old) & $56.6 \pm 2.5$ & $58.4 \pm 1.6$ & $64.0 \pm 1.5$ & $57.9 \pm 2.2$ & $59.4 \pm 1.0$ & N.S. \\
\hline BMI $(\mathrm{kg} / \mathrm{m})$ & $22.3 \pm 0.8$ & $24.0 \pm 0.4$ & $22.5 \pm 0.7$ & $23.4 \pm 0.6$ & $23.3 \pm 0.6$ & N.S. \\
\hline $\mathrm{TC}(\mathrm{mg} / \mathrm{d} l)$ & $188.4 \pm 11.7$ & $198.4 \pm 6.5$ & $210.0 \pm 5.4$ & $215.4 \pm 9.7$ & $203.6 \pm 4.0$ & N.S. \\
\hline $\mathrm{TG}(\mathrm{mg} / \mathrm{d} l)$ & $121.3 \pm 15.0$ & $155.4 \pm 13.4$ & $159.9 \pm 16.0$ & $170.1 \pm 18.3$ & $154.9 \pm 8.1$ & N.S. \\
\hline $\mathrm{HDL}-\mathrm{C}(\mathrm{mg} / \mathrm{d} l)$ & $44.7 \pm 4.2$ & $35.8 \pm 2.0$ & $39.1 \pm 2.0$ & $32.0 \pm 1.9$ & $40.0 \pm 1.2$ & $\mathrm{p}<0.05$ \\
\hline LDL-C $(\mathrm{mg} / \mathrm{d} l)$ & $121.6 \pm 11.2$ & $131.4 \pm 5.7$ & $138.9 \pm 6.7$ & $149.4 \pm 9.1$ & $136.0 \pm 3.8$ & N.S. \\
\hline $\mathrm{Lp}(\mathrm{a})(\mathrm{mg} / \mathrm{d} l)$ & $8.7 \pm 2.8$ & $22.6 \pm 3.2$ & $25.8 \pm 4.2$ & $36.4 \pm 4.7$ & $24.5 \pm 2.1$ & $\mathrm{p}<0.001$ \\
\hline LDL-C/HDL-C & $2.9 \pm 0.3$ & $4.1 \pm 0.3$ & $3.8 \pm 0.3$ & $5.1 \pm 0.4$ & $4.1 \pm 0.2$ & $\mathrm{p}<0.01$ \\
\hline LDL-C/TC & $0.63 \pm 0.02$ & $0.66 \pm 0.01$ & $0.66 \pm 0.01$ & $0.69 \pm 0.02$ & $0.66 \pm 0.01$ & N.S. \\
\hline Apo B $(\mathrm{mg} / \mathrm{d} l)$ & $93.6 \pm 7.8$ & $107.5 \pm 3.8$ & $107.3 \pm 4.6$ & $128.4 \pm 6.1$ & $110.4 \pm 2.7$ & $\mathrm{p}<0.01$ \\
\hline Apo B/A1 & $0.82 \pm 0.07$ & $1.23 \pm 0.07$ & $1.13 \pm 0.06$ & $1.54 \pm 0.09$ & $1.22 \pm 0.04$ & $\mathrm{p}<0.001$ \\
\hline LCAT (U) & $85.7 \pm 6.1$ & $77.6 \pm 3.7$ & $78.3 \pm 3.8$ & $81.5 \pm 4.9$ & $79.8 \pm 2.2$ & N.S. \\
\hline
\end{tabular}

$($ Mean \pm S.E.)

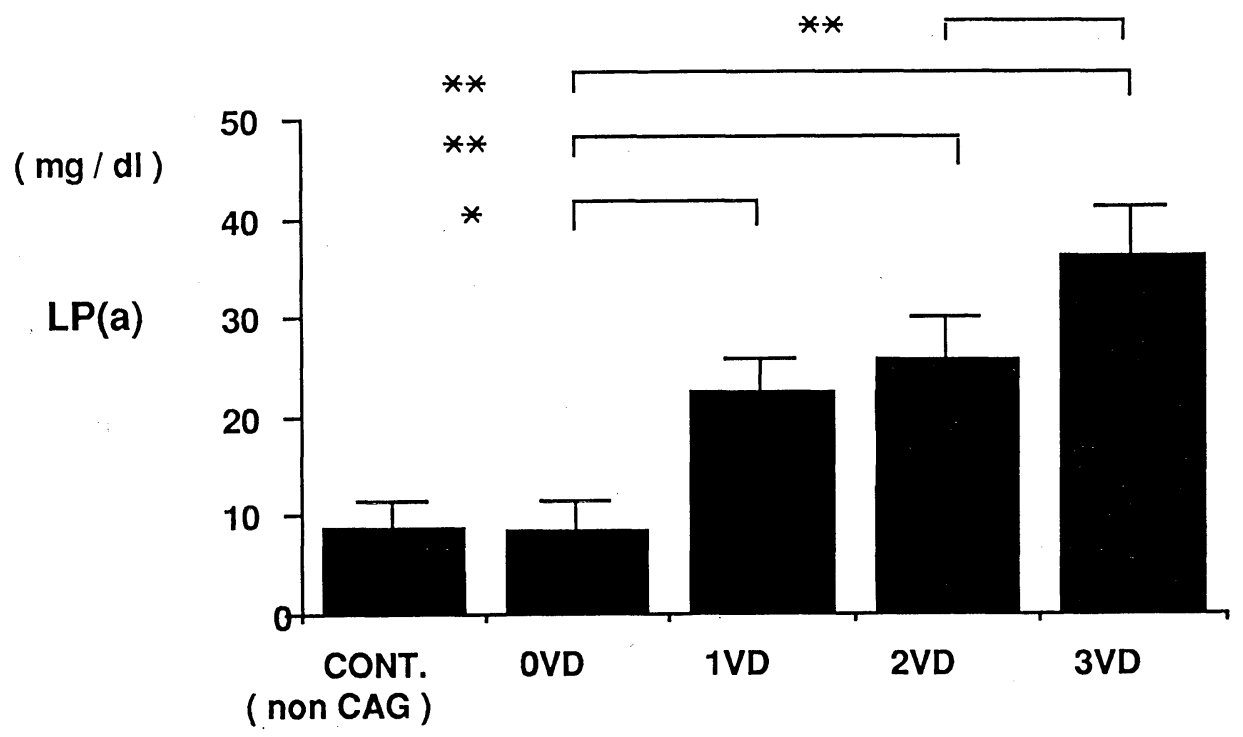

Wilcoxon rank - sum test

$* p<0.05 * * * 0<01$

Fig. 2 Comparison of $\mathrm{Lp}(\mathrm{a})$ levels among the CHD groups.

$\mathbf{L p}(a)$ と他の危険因子との関係 : 血中 $\mathrm{Lp}(\mathrm{a})$ 值 が冠動脈病変の重症度と相関のあることが判明し たが，この Lp(a) が他の危険因子と関連するかを 検討した。その結果 $\mathrm{Lp}(\mathrm{a})$ は, 年齢, 体格, 脂質, アポ蛋白, LCAT と有意な関係はなく, 独立した 危険因子と考えられた.

多变量解析 : CS を目的変数とし, 年齢, BMI,
TC，LDL-C/HDL-C，Lp(a) を従属変数として多 変量解析を行った. その結果, Lp(a) と LDL-C/ HDL-C が有意であった $(\mathrm{p}<0.01, \mathrm{p}<0.005)$.

危険因子保有者における高 $\mathbf{L p ( a )}$ 者の頻度 : 冠 危険因子として従来から指摘されている性別, 加 龄 (50 歳以上), 高血圧, 契煙, 糖尿病の血中 Lp(a) に対する影響を調べたが，いずれの危険因 
子の保有者における高 $\mathrm{Lp}(\mathrm{a})$ ( $\mathrm{Lp}(\mathrm{a})$ 濃度 $20 \mathrm{mg} / \mathrm{d} l$ 以上)の出現頻度には有意差が認められなかった。

\section{IV. 考 察}

Lp(a) は 1963 年 Bergにより血中に発見された 糖蛋白質7)で, アガロース電気泳動上, slow pre $\beta$ 位に泳動され, pre $\beta_{1}$ または sinking pre $\beta$ リポ 蛋白とも呼ばれている.

その後虚血性心疾患の発症に関連する危険因子 であるとの報告がある ${ }^{4,8,9)} .1987$ 年 McLean らは 遺伝子解析から apo(a)のアミノ酸配列を明らか にし10), plasminogen の Kringle 4 に相同な構造 のくり返しをもつことが明らかとなり，血液凝固 との関連も注目されている.

今回のわれわれの研究では, 日本人の冠動脈疾 患患者における Lp(a)の分布および Lp(a)が冠動 脈硬化症の発症と関連するか, さらにその進展度 に関与するかを，冠動脈造影を施行した患者にお いて検討した. その結果, 血中 $\mathrm{Lp}(\mathrm{a})$ 值は著しく $0 \mathrm{mg} / \mathrm{d} l$ に偏位した分布であったが，冠動脈疾患 患者を対象としたため $45 \mathrm{mg} / \mathrm{d} l$ に小さなピークを もち, 従来の本邦人での報告11) とは異なるが, 冠動脈疾患患者を対象としたDahlenの報告では ${ }^{9)}$, われわれの成績と同様 $40 \mathrm{mg} / \mathrm{d} l$ に 小さなピーク をもっていた.

本研究では, Lp(a) は, 冠動脈硬化の進展度と 強い関連があり，冠動脈狭窄が高度なほど $\mathrm{Lp}(\mathrm{a})$ 值が高いことが示された. また，他の危険因子と も相関しないので，独立した因子であることが判 った.

Lp(a) が冠動脈硬化を促進させる機序として, (1)動脈壁細胞の脂質取り込みの促進 ${ }^{12)}$, (2) LDL 受容体への LDL 結合を阻害し, atherogenic LDL 几変化させる ${ }^{13)}$, (3)凝集しやすい性質があり凝集 LDL が形成される可能性がある ${ }^{14)}$ ，(4)血管壁の glycosaminoglycans と結合しやすい15), (5) fibrin と結合しやすい16)，(6)血管壁上で plasminogen と 競合的に働き， thrombogenic に働く17)など多く の機序が考えられている. 本研究では冠動脈硬化 促進の機序については明らかにできなかったが, 今後この機序を解明するとともに, 治療法を研究 開発することが必要であると思われた。

\section{V. 結 論}

血中 $\mathrm{Lp}(\mathrm{a})$ 值は, 冠動脈病変の進展度と関連の 強い，独立した一因子であることが示された．健 康人においても Lp(a) を測定することにより虚血 性心疾患のハイリスク群を選び出すことが可能で あり，これらハイリスク群に対する治療法が確立 されれば，虚血性心疾患の発症を抑制することが 可能であると考えられる。

\section{文献}

1) Lipid Research Clinics Program: The Lipid Research Clinics Coronary Primary Prevention Trial Results. I. Reduction in Incidence of Coronary Heart Disease. J.A.M.A., 251 : 351-364 (1984).

2) Scanu, A. M. and Fless, G. M.: Lipoprotein(a) Heterogeneity and Biological Relevance. J. Clin. Invest., 85: 1709-1715 (1984).

3) Gensini, G. G.: The pathological anatomy of the coronary arteries of man. in Gensini, G. G.: Coronary Arteriography. Mount Kisco, New York, Futura Publishing Co. Inc., 1975, pp. 241-320.

4) Armstrong, V. W., Cremer, P., Eberle, E., Manke, A., Shulze, F., Wieland, H., Kreuzer, H. and Seidel, D.: The association between serum $\mathrm{Lp}(\mathrm{a})$ concentrations and angiographically assessed coronary atherosclerosis. Atherosclerosis, 62: 249-257 (1986).

5) Ikeda, T., Shibuya, Y., Senba, U., Sugiuchi, H., Araki, S., Uji, Y. and Okabe, H.: Automated immunoturbidimetric analysis of six plasma apolipoproteins: Correlation with radial immunodiffusion assays. J. Clin. Lab. Analy., 5: 90-95 (1991).

6) Friedewald, W. T., Levy, R. T. and Fredricksen, D. S.: Estimation of the concentration of lowdensity lipoprotein in plasma, without use of the preparative ultracentrifuge. Clin. Chem., 18: 499502 (1972).

7) Berg, K.: A new serum type system in man: the Lp system. Acta Pathol. Microbiol. Scand., 59: 369-382 (1963).

8) Kostner, G. M., Avogaro, P., Cazzolato, G., Marth, E., Bittolo-Bon, G. and Quinci, G. B.: Lipoprotein $\mathrm{Lp}(\mathrm{a})$ and the risk for myocardial infarction. Atherosclerosis, 38: 51-61 (1981).

9) Dahlen, G. H., Guyton, J. R., Attar, M., Farmer, J. A., Kautz, J. A. and Gotto, Jr., A. M.: Association of levels of lipoprotein $\mathrm{Lp}(\mathrm{a})$, plasma lipids, and other lipoproteins with coronary artery disease documented by angiography. Circulation, 74: 758765 (1986).

10) McLean, J. W., Tomlinson, J. E., Kuang, W.-J., 


\section{リポ蛋白 (a) の冠動脈硬化進展度に及ぼす影響}

Eaton, D. L., Chen, E. Y., Fless, G. M., Scanu, A. M. and Lawn, R. M.: cDNA sequence of human apolipoprotein(a) is homologous to plasminogen. Nature, 300: 132-137 (1987).

11) 川出真坂, 前田悟司, 飯田久也： $L p(a)$ リ蛋白に 関する研究 (第 1 報)——特異抗血清の調整法および 本邦人に打濃度分布。臨床病理, 32: 145-149 (1984).

12) Floren, C.-H., Albers, J. J. and Bierman, E. L.: Uptake of $\mathrm{Lp}$ (a) lipoprotein by cultured fibroblasts. Biochim. Biophys. Res. Commun., 102: 636-639 (1981).

13) Krempler, F., Kostner, G. M., Roscher, A., Hauslauer, F., Bolzano, K. and Sandhofer, F.: Studies on the role of lipoprotein(a) in man. J. Clin. Invest., 71: 1431-1441 (1983).

14) Gaubatz, J. W., Heideman, C., Gotto, Jr., A. M.,
Morrisett, J. D. and Dahlen, G. H.: Human plasma lipoprotein(a). Structural properties. J. Biol. Chem., 258: 4582-4589 (1983).

15) Bihari-Varga, M., Gruber, E., Rotheneder, M., Zechner, R. and Kostner, G. M.: Interaction of lipoprotein $\mathrm{Lp}(\mathrm{a})$ and low density lipoprotein with glycosaminoglycans from human aorta. Arteriosclerosis, 8: 851-857 (1988).

16) Harpel, P. C., Gordon, B. R. and Parker, T. S.: Plasmin catalyzes binding of lipoprotein(a) to immobilized fibrinogen and fibrin. Proc. Natl. Acad. Sci. U.S.A., 86: 3847-3851 (1989).

17) Hajjar, K. A., Gavish, D., Breslow, J. L. and Nachman, R. L.: Lipoprotein(a) modulation of endothelial cell surface fibrinolysis and its potential role in atherosclerosis. Nature, 339: 303-305 (1989). 


\title{
Summary
}

\section{Effects of the Serum Lipoprotein(a) Level on the Severity of Coronary Atherosclerosis}

\author{
Yuichi IshiKawa, Yoshio Fujioka, Takahiro Taniguchi, Ken Matsumoto, \\ Yoshinori Asaoka, Shin-ichiro TanaKa, Yoko Nishimura, Akira Nobusawa, \\ Hozuka AKITA and Mitsuhiro YoKoyAmA
}

First Department of Internal Medicine, Kobe University School of Medicine

Recently, high levels of serum lipoprotein(a) $(\mathrm{Lp}(\mathrm{a}))$ have been reported in connection with coronary atherosclerosis. However, little is known about the relationship of $\mathrm{Lp}(\mathrm{a})$ levels to the severity of coronary atherosclerosis.

We measured $\mathrm{Lp}$ (a) levels in 98 patients undergoing diagnostic coronary angiography (CAG group) and in 18 healthy subjects (control). The CAG group was divided into four subgroups by the number of the three involved major coronary vessels possessing more than $75 \%$ stenosis $(0,1$, 2, $3 \mathrm{VD}$ ), and the quantitative coronary lesion score (CS) of each CAG group patient was estimated by Gensini's method.

$\mathrm{Lp}(\mathrm{a})$ was measured by the single radial immunodiffusion method, while cholesterol (TC) and triglyceride (TG) were measured by the enzymatic method, HDL-cholesterol (HDL) by the precipitation method, apolipoprotein A1 and B (apo A1, apo B) by the turbidometric immunoassay method, and LCAT by Akanuma's method. The LDLcholesterol (LDL) was calculated by Friedewald's formula.
The mean value of the $\mathrm{Lp}(\mathrm{a})$ levels was 22.1 $\mathrm{mg} / \mathrm{d} l$, and the median was $19.4 \mathrm{mg} / \mathrm{d} l$. The mean $\mathrm{Lp}$ (a) level was $8.9 \mathrm{mg} / \mathrm{d} l$ in the controls, $8.7 \mathrm{mg} /$ $\mathrm{d} l$ in $0 \mathrm{VD}, 22.6 \mathrm{mg} / \mathrm{d} l$ in $1 \mathrm{VD}, 25.8 \mathrm{mg} / \mathrm{d} l$ in $2 \mathrm{VD}, 36.4 \mathrm{mg} / \mathrm{d} l$ in $3 \mathrm{VD}$. The Lp(a) level was significantly associated with the number of vessels involved by the non-parametric statistical method. CS was significantly correlated with $\mathrm{Lp}(\mathrm{a}), \mathrm{TC}$, LDL and apo A1 levels or LDL/HDL, LDL/TC, and the apo B/A1 ratios by univariate analysis. However, the level of serum $\mathrm{Lp}(\mathrm{a})$ was not correlated with other lipids, lipoproteins, apolipoproteins, age, or the body mass index. The frequency of a high $\mathrm{Lp}(\mathrm{a})$ level over $20 \mathrm{mg} / \mathrm{d} l$ was not associated with diabetes, hypertension, smoking, gender, or old age (over 50 years old).

Thus, serum $\mathrm{Lp}(\mathrm{a})$ levels appear to be a risk factor in initiating and enhancing coronary atherosclerosis.

Key words: lipoprotein(a), coronary artery disease, hypercholesterolemia, coronary risk factors. 